\title{
Effects of Sulfur, Phosphorus, and Nitrogen Application on the Growth and Yield of Sweet Potatoes Grown on Fredensborg Clay Loam"
}

\author{
A. A. Navarro ${ }^{2}$ and D. S. Padda ${ }^{3}$
}

\begin{abstract}
The effect of sulfur, nitrogen, and phosphorus applications on the growth and yield of sweet potatoes grown on Fredensborg clay loam was evaluated. Although there was no reduction in soil $\mathrm{pH}$ as a result of sulfur application, yield increased with increased rates of sulfur. Yields increased significantly with nitrogen applications. Phosphorus application did not significantly affect the yield.
\end{abstract}

\section{INTRODUCTION}

The Virgin Islands soils formed of materials derived from basic volcanic rocks and soft limestone are exceedingly high in calcium, magnesium, sodium, and potassium (7). Thus, the soil reaction is highly alkaline with pH sometimes as high as 11.5 (2). Such high alkalinity is not desirable for most agronomic crops. Vegetable crops in particular do best in soils with $\mathrm{pH}$ ranging from 5.5 to 6.5 (5).

Sulfur is an acid-forming material. When added to the soil, it is oxidized according to the following reactions (1):

$$
\begin{gathered}
\text { Aerated Soil- } \mathrm{S}+1 \frac{1}{2} \mathrm{O}_{2} \stackrel{\text { T. thioxidans }}{\longrightarrow} \mathrm{H}_{2} \mathrm{SO}_{4} \\
\text { Flooded Soil- } 5 \mathrm{~S}+6 \mathrm{KNO}_{3}+\mathrm{H}_{2} \mathrm{O} \stackrel{\text { T. Dentrificans }}{\longrightarrow} \mathrm{H}_{2} \mathrm{SO}_{4}+3 \mathrm{~N}_{2}
\end{gathered}
$$

The acid produced in the above reactions reduces soil alkalinity and transforms sodium carbonates to less harmful forms (3).

Sulfur from a local oil refinery could be made readily available for crop production in the Virgin Islands. The refinery produces huge amounts of pelletized sulfur as a by-product in petroleum distillation.

This study was conducted to determine the effects of sulfur applications on the acid-base balance of the soil, and on the growth and yield of sweet potatoes. Response of sweet potatoes to nitrogen and phosphorus, two elements most deficient in Virgin Islands soils (4) was also evaluated.

\section{MATERIALS AND METHODS}

These studies were conducted at the College of the Virgin Islands Agricultural Experiment Station at Kingshill, St. Croix, U. S. Virgin

\footnotetext{
${ }^{1}$ Manuscript submitted to Editorial Board, August 5, 1981.

${ }^{2}$ Vegetable Specialist, Agricultural Experiment Station, College of the Virgin Islands.

${ }^{3}$ Director of the Agricultural Experiment Station and Cooperative Extension service of the College of the Virgin Islands.
} 
Islands. The climate is tropical with an annual average maximum and minimum temperatures of $30^{\circ} \mathrm{C}$ and $23^{\circ} \mathrm{C}$, respectively. The average annual rainfall is $1092 \mathrm{~mm}$.

The soil is a Fredensborg clay loam, 25-38 cm thick. Underneath the surface clay is a layer of limestone or marl. The soil $\mathrm{pH}$ ranges from 7.5 to 8.2 .

Sweet potatoes cv. Pelican Processor were planted May 7, 1980, vine cuttings about $30 \mathrm{~cm}$ long. The cuttings were planted in the center of raised plots $(1.5 \mathrm{~m} \times 6.0 \mathrm{~m})$. The plants were set in single rows with a distance of $60 \mathrm{~cm}$ between cuttings. Cuttings were planted at a slant with approximately $3 / 4$ of the length under the ground.

Elemental sulfur used in the study was obtained from the oil refinery on St. Croix. Since the sulfur came in granulated form, it was ground to pass through a $1.6 \mathrm{~mm}$ mesh screen.

Three rates of sulfur, 0,2246 , and $4492 \mathrm{~kg} / \mathrm{ha}$; two rates of nitrogen (from ammonium sulfate), 280 and $560 \mathrm{~kg} / \mathrm{ha}$; and two rates of phosphorus (from superphosphate), 0 and $280 \mathrm{~kg} / \mathrm{ha}$ were selected. The different rates of sulfur, nitrogen, and phosphorus were combined in split factorial to form 12 different treatments. The treatments were arranged in randomized complete block design.

Sulfur was applied a week before planting. Nitrogen and phosphorus were added in split-applications: half at planting and the other half at 1 month after planting. Sulfur, ammonium sulfate and superphosphates were broadcast and immediately raked into the soil.

Five months and eighteen days after planting, the sweet potatoes were harvested. Data on vine weight, number, and weight of marketable tubers were taken. Soil samples taken from each plot were analyzed for $\mathrm{pH}$.

\section{RESULTS AND DISCUSSION}

Table 1 shows the effects of the applications of varying rates of elemental sulfur, nitrogen and phosphorus on yields. Significant increases in yields were obtained with increased rates of sulfur. Yield increased approximately $30 \%$ over the control ( 0 sulfur) with sulfur application rate of $2246 \mathrm{~kg}$ per hectare. A further increase in yield resulted with a higher rate of sulfur application. At the rate of $4492 \mathrm{~kg}$ of sulfur per hectare, yield increased approximately $117 \%$ over the control.

No significant reduction in soil $\mathrm{pH}$ was observed even with the highest sulfur application rate of $4492 \mathrm{~kg}$ per hectare (table 2). The failure of sulfur to reduce soil $\mathrm{pH}$ was apparently due to a number of factors. The sulfur materials used in the study were not agricultural grade. Evidently, the sulfur particles were not fine enough to react rapidly with the soil, and the time ( 5 months) in which the sulfur reacted with the soil was apparently not long enough to have considerable effect on soil $\mathrm{pH}$. It is 
also possible that even the highest amount of sulfur used in the study was not sufficient to overcome the large amount of lime present in the soil.

Although the soil $\mathrm{pH}$ was not significantly reduced by sulfur application, the addition of sulfur may have created some favorable $\mathrm{pH}$ condition in the microenvironment of the plant roots, which is not discernible by present method of $\mathrm{pH}$ measurements. Such conditions may have been partly responsible for the positive response of sweet potatoes to sulfur application. It is also possible that the addition of sulfur resulted in

TABLE I.-Effects of $S, N$ and $P$ on the yields of sweet potatoes, tons per hectare

\begin{tabular}{|c|c|c|c|c|c|}
\hline & \multicolumn{3}{|c|}{ Sulfur, kg/ha } & \multirow{2}{*}{ Total } & \multirow{2}{*}{ Mean } \\
\hline & 0 & 2246 & 4492 & & \\
\hline \multicolumn{6}{|l|}{ Nitrogen } \\
\hline $280 \mathrm{~kg} / \mathrm{ha}$ & 9.9 & 19.7 & 25.6 & 55.2 & $18.4^{\mathrm{a}}$ \\
\hline $560 \mathrm{~kg} / \mathrm{ha}$ & 7.8 & 13.9 & 17.1 & 38.8 & $12.9^{\mathrm{b}}$ \\
\hline \multicolumn{6}{|l|}{ Phosphorus } \\
\hline $0 \mathrm{~kg} / \mathrm{ha}$ & 11.3 & 16.0 & 20.2 & 47.5 & $15.8^{\mathrm{a}}$ \\
\hline $280 \mathrm{~kg} / \mathrm{ha}$ & 10.0 & 16.9 & 21.9 & 48.8 & 16.2 \\
\hline TOTAL & 39.0 & 66.5 & 84.8 & & \\
\hline MEAN & $9.8^{\mathrm{c}}$ & $16.6^{\mathrm{b}}$ & $21.2^{\mathrm{a}}$ & & \\
\hline
\end{tabular}

${ }^{1}$ Means with one or more letters in common do not differ significantly at the 0.05 level of significance.

TABLE 2.-Effect of $S, N$ and $P$ applications on soil $p H$

\begin{tabular}{lcccc}
\hline & \multicolumn{3}{c}{ Sulfur, kg/ha } & \multirow{2}{*}{ Mean $^{1}$} \\
\cline { 2 - 3 } & 0 & 2246 & 4492 & \\
\hline Nitrogen & & & & 7.66 \\
$280 \mathrm{~kg} / \mathrm{ha}$ & 7.7 & 7.7 & 7.6 & 7.66 \\
$560 \mathrm{~kg} / \mathrm{ha}$ & 7.7 & 7.6 & 7.7 & 7.73 \\
Phosphorus & & & & 7.63 \\
$0 \mathrm{~kg} / \mathrm{ha}$ & 7.8 & 7.7 & 7.7 & \\
$280 \mathrm{~kg} / \mathrm{ha}$ & 7.7 & 7.7 & 7.5 & \\
\hline MEAN $^{1}$ & 7.72 & 7.67 & 7.62 & \\
\hline
\end{tabular}

${ }^{1}$ Differences not significant.

greater availability of some elements. According to Bear (1), there have been cases, although evidence is not yet conclusive, where acid treatment insufficient to react with most excess lime in the soil, has increased nutrient uptake of phosphorus, iron and zinc (1).

There was also an indication that sulfur may be deficient in the soil selected for the study. Yellowing of the young upper leaves of the sweet potatoes, a characteristic of sulfur deficiency in many crops (6), was very often observed on treatments not receiving sulfur or ammonium sulfate.

As shown in table 1, no yield response was obtained with $\mathrm{P}$ application. 
Comparable yields were obtained at phosphorus rates of 0 and $280 \mathrm{~kg}$ $\mathrm{P}_{2} \mathrm{O}_{5}$ per hectare. Apparently, the soil on which the sweet potatoes were grown has adequate phosphorus.

In the case of nitrogen, considerable increase in yield was obtained with application of $280 \mathrm{~kg} \mathrm{~N}$ per hectare. Yield was reduced, however, when nitrogen application was increased to $560 \mathrm{~kg} \mathrm{~N}$. Table 3 shows that high levels of nitrogen produced much vine growth, obviously at the expense of tuber production.

TABLE 3.-Weight of vines as influenced by $S, N$ and $P$ applications, tons per hectare

\begin{tabular}{|c|c|c|c|c|c|}
\hline & \multicolumn{3}{|c|}{ Sulfur, kg/ha } & \multirow{2}{*}{ Total } & \multirow{2}{*}{ Mean } \\
\hline & 0 & 2246 & 4492 & & \\
\hline \multicolumn{6}{|l|}{ Nitrogen } \\
\hline $280 \mathrm{~kg} / \mathrm{ha}$ & 28.0 & 27.3 & 27.4 & 82.7 & $27.6^{a^{1}}$ \\
\hline $560 \mathrm{~kg} / \mathrm{ha}$ & 34.7 & 35.2 & 31.5 & 101.4 & $33.8^{\mathrm{b}}$ \\
\hline \multicolumn{6}{|l|}{ Phosphorous } \\
\hline $0 \mathrm{~kg} / \mathrm{ha}$ & 25.0 & 22.8 & 24.1 & 71.9 & $24.0^{a}$ \\
\hline $280 \mathrm{~kg} / \mathrm{ha}$ & 25.2 & 23.9 & 26.1 & 75.2 & $25.1^{a}$ \\
\hline TOTAL & 112.9 & 109.2 & 109.1 & & \\
\hline MEAN & $28.2^{a}$ & $27.3^{\mathrm{a}}$ & $27.3^{\mathrm{a}}$ & & \\
\hline
\end{tabular}

${ }^{1}$ Means with one or more letters in common do not differ significantly at the 0.05 level of significance.

\section{RESUMEN}

El efecto de aplicaciones de azufre, fósforo y nitrógeno sobre el crecimiento y el rendimiento de la batata (Ipomoea batatas) se evaluó en un suelo franco-arcilloso de la serie Fredensborg (del orden de los Mollisols). Aunque el pH del suelo no bajó como resultado de las aplicaciones de azufre, el rendimiento aumentó con incrementos de este elemento. Incrementos significativos en el rendimiento se obtuvieron con aplicaciones de nitrógeno. Las de fósforo no lo afectaron significativamente.

\section{LITERATURE CITED}

1. Bear, F. E., 1967. Chemistry of soil, Reinhold Publishing Company, New York.

2. Bryan, H. H., 1973. Feasibility of vegetable production on St. Croix, Virgin Islands, Col. Virgin Islands, Exp. Stn., St. Croix, U.S. Virgin Islands, Unpublished.

3. Buckman, H. O., and Brady, N. C., 1966. The nature and properties of soils, The McMillan Company, New York.

4. Conje, A. M. and Padda, D. S., 1976. Sorghum in the Virgin Islands, Farmers Bull. No. 2, Agric. Exp. Stn., Col. Virgin Islands, St. Croix, U. S. Virgin Islands.

5. Knott, J. E., 1957. Handbook for vegetable growers, John Wiley and Sons, Inc., New York.

6. Porras, E., 1980. Identifying sulfur deficiency, World Farming 22 (3): 36-41.

7. Rivera, L., Wayne, D., Jensen, E., Davis, L., Palmer, C., Jackson, L., and McKinzie W., 1970. Soil survey of the Virgin Islands of the United States, USDA, Washington, D. C. 